\title{
Development of a Holistic Competency Model for Design Managers
}

\author{
Chen Xianga, Wenqing Yang \\ aPeking University \\ ${ }^{\circ}$ Tongji University \\ *Corresponding author e-mail: wei.liu@kcl.ac.uk
}

\begin{abstract}
:
Design management is with growing importance for companies in multiple industrial sectors to build competitive advantages and strengthen organizational flexibility, in which design managers play critical roles. However, due to lack of studies into the gap between how organization implement design and how design managers perform their work, the management of design into the micro level still result in failures and the measurement of design managers remain unclear. A possible way to reach a holistic view of design managers is by building a competency model and seeking the links with the organizational environment. This paper therefore aims to study the competency of design managers, by introducing a model for measuring competencies and test the correlation with organizational factors, based on academic theoretical findings and industrial data analysis. The results would lay the ground for future research on design managers' competency and provide practical implications for organizations.
\end{abstract}

Keywords: design manager; competency; organizational environment

\section{Introduction}

Today's economic conditions are quite challenging. The weak economic recovery, intensified global competition and unforeseen challenges have caused the uncertainty to continuously rise. Design is used as a strategic tool for product differentiation and innovation to tack the uncertainty of corporate environment (Lockwood, 2004; de Mozota, 2006) and bring better financial performance (Gemser \& Leenders, 2001; Moultrie et al., 2009; Talke, Salomo, Wieringa, \& Lutz, 2009). When companies regard design as a way to gain competitive advantages, design managers are also given various roles and responsibilities.

Design managers are seen as a pivot to link design team responsible for design execution and top management in charge of strategy (Bucolo \& Matthews, 2011). Design managers are active in multiple organizational levels (Best, 2006; Carr, Halliday, King, Liedtka, \& Lockwood, 2010; Chung, 
1998) and expected as the emerging bridge to cross design and business(Chen et al., 2010). Moreover, Design managers also take dual function in leading and managing design (McBride, 2007; Nam \& Jung, 2008).

Considering managing and leading design are both necessary for organizations (Turner \& Topalian, 2002; Miller \& Moultrie, 2013), this paper decides to use design managers as a general term for both design managers and design leaders defined by the past research.

Given the critical socio-economic value of design and the complex requirements for design managers, it is necessary to deconstruct how organizations implement design into the micro foundations of design managers, thus to portray this micro foundation and feature the higher organizational construct behind.

\section{Literature review}

\subsection{Competency}

McClelland (1973) has laid the groundwork for competency, defining which as the personal ability factors that distinguish people from the general average in the occupational outcomes. Large amount of research has since conducted. First, competencies are holistic, including knowledge, attitudes and know-how (McLagan, 1980; R. E. Boyatzis, Leonard, Rhee, \& Wheeler, 1996). Second, competencies are dynamic, which are matched with different work situations and job requirements (Sandberg, 2000; Cockerill, Hunt, \& Schroder, 1995). Third, competencies can be observed and measured, through building an appraisal scale by a series of methods, such as behaviour event interviews and statistical analysis (Bell \& Fletcher, 1992). Fourth, competencies can drive performance, which can be used to predict individual performance (Byham, 1996; Ledford Jr, 1995).

With the given features, it is believed that competency is the most appropriate concept to serve as the definition for micro foundations of design managers. It is systematic and holistic. Its dynamic nature resonates with the aim to detect relation with organizations. Furthermore, the abundant existing studies also provide this study with rigorous measurement methods.

\subsection{Design management competencies}

The foundation of general management competencies was laid by Boyatzis (1982), which was summarized into 6 clusters and 19 specific competencies. Particular studies on design management competencies also emerged initially as studies into skills. Dickson, Schneier, Lawrence, and Hytry (1995) analysed 5 clusters of design management skills from CEOs. Ricardo Chiva and Alegre (2009) quantitatively tested the correlation between design investment and firm performance with the same skill clusters, which confirmed the clusters' significance. Based on quantitative interviews, Miller and Moultrie (2013) clustered skills of design managers into 5 categories, which comprehended the holistic nature of competencies and fit into various levels of organizational activities. Kang, Chung, and Nam (2015) pioneered in introducing the theories and modelling methods of building a competency model into design management. From that, systematic and quantitative view of design management competencies was recognized and differentiation with regard to organizational business was also underlined. 
Referring to the literature of design management competencies (see in table 1), we rearrange the classification into thinking, thinking, profession, business, team, project by picking the most mentioned ones as the directions.

Table 1 Past classification of design management competencies

\begin{tabular}{l|l}
\hline Classification of design management & References \\
\hline $\begin{array}{l}\text { Basic skills, specialized skills, involving others, organizational change, } \\
\text { innovation skills }\end{array}$ & (Dickson et al., 1995) \\
\hline $\begin{array}{l}\text { Meta competences, social competences, functional competences, } \\
\text { cognitive competences }\end{array}$ & (Kang et al., 2015) \\
\hline $\begin{array}{l}\text { Cognitive skills, interpersonal skills, business skills, strategic skills, } \\
\text { design skills }\end{array}$ & (Miller \& Moultrie, 2013) \\
\hline \begin{tabular}{l} 
Differentiator, integrator, transformer, business \\
\hline $\begin{array}{l}\text { Knowledge competencies, creative competencies, team } \\
\text { competencies }\end{array}$
\end{tabular} & (de Mozota, 2006) \\
\hline
\end{tabular}

\section{Thinking}

Design managers have unique attitudes, habits and thinking modes. They can avoid common management prejudices (Dunne \& Martin, 2006). They believe that problems and solutions are coevolving (Restrepo \& Christiaans, 2004). They are also good at creative thinking, such as analogical reasoning (Mullins, Mullins, Mullins, \& Komisar, 2009) and abstraction (Linsey, Markman, \& Wood, 2012) to stimulate novel solutions.

\section{Profession}

Formal design training and extensive industry experience are necessary (Lee \& Cassidy, 2007). The technical, aesthetic and craft abilities are central to design leadership (Miller \& Moultrie, 2013). Consideration is taken into the combination of prototype, narrative and visualization (Van den Hende et al., 2007) and the stakeholders' perception (Mugge \& Dahl, 2013).

\section{Business}

Some of the top management tend to marginalize designers to keep the company stable (K. Elsbach \& Flynn, 2008). Other departments also have different language systems with design. Therefore, a common language area, effective language conversion (Micheli, Jaina, Goffin, Lemke, \& Verganti, 2012) and mutual understanding of identities (K. D. Elsbach, Brown-Saracino, \& Flynn, 2015) also need to be built.

\section{Team}

Designer's breadth of design technology and material knowledge, the transfer of industry experience, leading motivations are considered in building a team (Wolfradt \& Pretz, 2001). Aside from crafting, diverse roles of designers should be given full play (Lau, Beckman, \& Agogino, 2012). Particular treatment (Waples \& Friedrich, 2011) and encouragements (Shalley \& Gilson, 2004) are taken for creative nature of designers.

\section{Project}

The design project plan should set the boundaries, imply a solution direction, and evaluate the risks (Lauche, 2007). Resource allocation should be made to reach the overall high consumer life cycle value (Turner, 2016) and lower development cost (Langerak, Hultink, \& Griffin, 2008). Decisions made in a project also should be anchored as user-centric to form consensus and ppush forward work progress (Ratneshwar, Shocker, Cotte, \& Srivastava, 1999). 


\subsection{Organizational factors}

To accomplish a holistic view, the correlation between competencies and organizational environment worth further studying. Boyatzis (2008) has underlined that organizational environment, which referred to culture and climate, structure and systems, maturity of the industry and strategic positioning within it and larger context, were predicted to impact the demonstration of competencies. Particularly in design management, Noble and Kumar (2010) predicted that organizational factors, such as resource constraints, cross functional integration and design culture, should impact the implement of design levers in achieving design goals. Moultrie, Clarkson, and Probert (2007) also summarized organizational factors of successful design management. Heskett and Liu (2012) came up with 6 organizational dimensions for building design capacity. Based on that, an adapted framework with more detailing measurement was proposed (Storvang, Jensen, \& Christensen, 2014).

This paper tries to make the possible influencing organizational factors into structured dimensions which are shown in table 2 .

Table 2. Influencing factors in organizational environment.

\begin{tabular}{|c|c|c|}
\hline Organizational factors & Descriptions & References \\
\hline Organizational strategy & $\begin{array}{l}\text { Company invests more human and financial } \\
\text { resources in the design function. }\end{array}$ & $\begin{array}{l}\text { (Gemser \& Leenders, 2001; } \\
\text { Beckman \& Barry, 2007; Cooper \& } \\
\text { Kleinschmidt, 1995; Dell'Era \& } \\
\text { Verganti, 2009) }\end{array}$ \\
\hline Organizational culture & $\begin{array}{l}\text { Company has a culture that values design, supports } \\
\text { creativity, and is user-centred. }\end{array}$ & $\begin{array}{l}\text { (Dell'Era, Marchesi, \& Verganti, } \\
\text { 2010; Petre, 2004; Im \& Workman } \\
\text { Jr, 2004; Acar, Tarakci, \& van } \\
\text { Knippenberg, 2019; R Chiva \& } \\
\text { Chiva-gómez, 2014) }\end{array}$ \\
\hline Organizational structure & $\begin{array}{l}\text { Design function is involved in multiple stages of } \\
\text { product development. }\end{array}$ & $\begin{array}{l}\text { (Roper, Micheli, Love, \& Vahter, } \\
\text { 2016; Bloch, 1995; Kahn, 2001) }\end{array}$ \\
\hline
\end{tabular}

\section{Method}

\subsection{Research Setting}

To avoid biases, the design management competencies should be warranted by sourcing from a broad scope of industry settings. A rigorous scale for measuring competencies need be made and tested with industrial data. The planned research steps are as follows.

To ensure the scale is with reliable indicators, a base of design management competencies should be founded by academic literature review and industrial interviews. Discussion with experts help further cluster key items. To strengthen the research with empirical evidence, a survey is made to gather industrial data. Lastly, to guarantee the reliability and validity, quantitative analysis is implemented upon the survey data to classify the competency clusters into dimensions and verify the predicted relationships with organizational factors.

\subsection{Scale Making}

Firstly, this paper reviewed academic resource that focused on design and also conditioned with lead, management, business and strategy from academic libraries powered by EBSCO, Scopus and Google Scholar. 421 papers were initially screened through reading the title of the papers. 
Following this, a more detailed screening was conducted by reading the abstract and table. Finally, the papers were read in full, resulting in 135 papers, from which the core items were extracted to form the literature item base.

Secondly, 8 design managers (showing in table 3 ) were invited for interview and discussion. The selection criteria were as follows. The interviewees' organizations should have a design function unit and regard producing products and services as their core business. Moreover, the interviewees should take management positions in design, at different organizational levels and with enough years of experience. There were mainly two tasks for the interviewees. The first was taking a behaviour interview, in which they were asked questions about their own competencies, current job requirements and past experience. Every interview lasted for 60-90 minutes, which resulted in data of over 55000 words. The core items were extracted and coded through NVivo. The second task was asking them to group and refine the items. The descriptions were also verified by these professional interviewees. Finally, the items were classified into 34 core competencies and 13 clusters, which are shown as part of table 9 .

Thirdly, with the 13 competency clusters and 3 organizational factors integrated into the columns of the survey scale, the questionnaire was made in the form of 7-point Likert scale ranging from "strongly agree" to "strongly disagree".

\subsection{Survey}

To verify with statistical evidence, a large amount of structured data was needed. The questionnaires were sent in the digital form through channels of companies, participants in related course or forums and contact lists in industry associations. The qualified respondents should accord with the criteria that they took management positions in design function which is a integrate functional unit inside the organizations that primarily profit from producing products and services. The data was collected as random sample from 65 managers under multiple industrial settings, in which 61 responses from 61 different organizations were completed and qualified for the research targeted range. The basic information of the survey respondents is shown in table 4.

\section{Analysis and results}

In this section, reliability ( $\alpha=0.931)$ within the data of competencies and reliability $(\alpha=0.781)$ within the data of organizational factors are both over the critical value of 0.6 , which means the data sources are qualified for quantitative analysis.

Therefore, initial analysis is given to provide a general understanding. Exploratory factor analysis is then implemented to reach a structured competency model. After that, regression analysis between the competency dimensions and the predicted organizational factors is performed to explore whether particular correlations exist.

\subsection{Initial analysis for competencies and organizational factors}

According to the average importance valued by the survey respondents, the ranking of design management competencies are shown in table 5 , which are all scored between "relatively agree" 
and "agree", indicating that the previously obtained competency clusters are all approved by design managers. From the average ranking, we can find the following clues.

From the top competencies, we can see that design managers are generally confident about their competencies in the cognitive aspect, which can be regarded as the most basic features.

It also can be seen from the middle positions that the tactical competencies, toward management of project or designers, are measured slightly prior than strategic competencies.

Drawn from the bottom rankings, design managers are likely to lack business and technical competencies. This shows that even managers of design may still be more introverted into design rather than serving the core business of the whole organization, which can be seen as a limitation.

We also obtain initial statistic features of the potentially important organizational factors (details included in table 6).

The participation of design functions in multiple stages of product development and the company's culture that supports design are the most supported factors, which has become common operating mechanisms among enterprises.

However, it can be seen that design might be with less strategic importance, since few organizations actually invest more resources in design than their competitors. This is not only due to that it is difficult for design to prove direct returns, but also due to the resource constraint of the organization.

\subsection{Exploratory factor analysis for competencies}

Since KMO-value of 0.818 is above the critical value of 0.7 and the significance of Bartlett's spherical test is 0 , exploratory factor analysis is allowed to perform, which avoid subjectivity by manual clustering and also prepares for the correlation test with organizational factors. The results extract 13 variables into 5 factors, which represents 5 dimensions of competencies that account for $84.797 \%$ of the information from the original data (see details in table 7). The 5 dimensions are names as design team leadership, design profession, design management thinking, design business strategy and design resource gathering.

In the first dimension, there is no wonder that competency clusters about managing designers aggregate together. However, with making design strategy and managing design process also extracted into this domain, it turns out that the competencies toward project and team, which we assumed as two different directions, are potentially interrelated, which may even be found to facilitate each other if further research is implemented. This united competency dimension lead us to conclude this dimension as "design team leadership".

The second dimension are constituted together as what design professionals must have. In order to produce a design work, translating user needs into feasible concepts is primary, then adequate design manual skills are required and the latter is undoubtedly the successful communication. Therefore, we propose the name "design profession" for this competency dimension.

There is no doubt that the third dimension emerges, which shows consistency between how managers think and what attitudes managers possess. Since both competency clusters are cognitive 
ones and necessary for a qualified manager, the dimension that these two reside in is named as "design management thinking".

While following corporate strategy is engaged in the fourth dimension, a clear distinction is that the making of design strategy doesn't belong to this dimension. It suggests inconformity between how to develop design in an organization and how to serve the organization's core business. Therefore, this dimension is essentially about stretching design to connect to the organizational core business, named as the competency dimension of "design business strategy".

The last competency dimension, named as "design resource gathering", remarkably loads on a single dimension differently from the design business strategy dimension or from the design team leadership dimension. This separation shows that striving for resource support may not necessarily concur with other competencies.

\subsection{Regression analysis for correlations with organizational factors}

Regression analysis is implemented to find out whether significant correlations exist between the competency dimensions and the predicted organizational factors. The results are showing in table 8 .

In terms of design team leadership dimension, only the organizational culture factor has a significant impact with a significance of 0.044 less than the critical value of 0.05 . As to dimension of design management thinking, the organizational structure factor's significance is 0.005 less than 0.05 , indicating that the multiple-stage design participation support design management thinking. Concerning competency dimension of design business strategy, the organizational culture and organizational structure factors have significance of 0.001 and 0.027 , both less than 0.05 , indicating significant correlation with the design business strategy dimension. With regard to dimension of design resource gathering, only the organizational strategy factor has strong impact with significance of 0.013 over 0.05 . In the design profession dimension, the significance of all organizational factors on it are not less than 0.05 , indicating that no organizational factors predicted have significant impact on design profession dimension.

\section{Discussion}

\subsection{Implication}

Implications are provided for companies who are interested in cultivating competitive design managers.

First, if a company wants to elevate the management thinking competencies of its design managers, making adaptions in organizational structure to involve design function in multiple stages should be a critical point. Second, when a company treats the team leadership competencies of its design managers as significant, the building of organizational culture that values design should never be ignored. Third, if the dimension of business strategy competencies of design managers is given great importance, this company should have design involved in more stages to stimulate contact with other functions and dedicate in building its organizational culture. Fourth, while a company expects its design managers to be stronger resource gatherers, this company need to build a design focused strategy by investing more human and financial resources in the design function. Lastly, 
competencies in the design profession, are not affected by any predicted organizational factors, which suggest that design profession competencies may mainly rely on design managers themselves rather than the organization. The mentioned implications further resonates with the research that if a company wants to make design as its leading functional discipline, regarding design as innovation process, communicating design value and supportive design culture are key aspects(Aftab, 2013). If companies need to get ready for innovation, design could be useful to identifying the existed innovation barriers, improving existing practices and forming strategy coping with challenges(Gribbin, Spencer, \& Bailey, 2018).

\subsection{Limitation}

This study is limited in the following aspects. First, research on the competencies of design managers, especially with empirical analysis, is still in the preliminary stage. Therefore, the feasibility of scale generated in this research remains to be verified by subsequent studies. Second, the amount of data collected in the survey phase is limited and need to be verified with more experts. Third, although we have tried our best to achieve the independence of the descriptions, it is still difficult to make all the item completely exclusive. Lastly, although the objective quantitative analysis methods are used, it is difficult to avoid the influence of subjectivity in the previous qualitative research stages. Hence, more research with rigorous methodology is expected to be developed in the future.

\section{Conclusion}

This paper aimed to reach a holistic view toward competencies and organizational traits of design managers, particularly to solve three key problems. The first is what competencies design managers possess. The second is how the competencies are collectively structured together for design managers. The third is how the competencies are impacted by the organizational environment. The main contributions are as follows.

First of all, combined by the literature review and industrial interviews, 34 core competencies, 13 competency clusters and 3 presumed influencing organizational factors for design managers were retrieved. Second, exploratory factor analysis was implemented upon the survey data to aggregate the competency clusters into 5 competency dimensions (see in table 7). Thus the 3-layer competency model was built and each dimension was further discussed (see in table 9). Lastly, regression analysis was implemented to find patterns between competency dimensions and organizational factors (see in table 8). It was proved that factors in organizational culture, organizational structure and organizational strategy all can elevate particular competency dimension of design managers, which provided implications of real-life practices for organizations.

\section{References}

Lockwood, T. (2004). Integrating design into organizational culture. Design Management Review, 15(2), 32-39. doi:https://doi.org/10.1111/j.1948-7169.2004.tb00159.x 
de Mozota, B. B. (2006). The Four Powers of Design: A Value Model in Design Management. Design Management Review, 17(2), 44-53. doi:https://doi.org/10.1111/j.1948-7169.2006.tb00038.x

Gemser, G., \& Leenders, M. A. (2001). How integrating industrial design in the product development process impacts on company performance. Journal of Product Innovation Management: AN INTERNATIONAL PUBLICATION OF THE PRODUCT DEVELOPMENT \& MANAGEMENT ASSOCIATION, 18(1), 28-38.

Moultrie, J., Livesey, F., Malvido, C., Beltagui, A., Pawar, K., \& Riedel, J. (2009). Design funding in firms: a conceptual model of the role of design in industry.

Talke, K., Salomo, S., Wieringa, J. E., \& Lutz, A. (2009). What about design newness? Investigating the relevance of a neglected dimension of product innovativeness. Journal of Product Innovation Management, 26(6), 601-615.

Bucolo, S., \& Matthews, J. (2011). Design-led innovation-Exploring the synthesis of needs, technologies and business models. Paper presented at the 2011 Participatory Innovation Conference Proceedings.

Best, K. (2006). Design management: managing design strategy, process and implementation: AVA publishing.

Carr, S. D., Halliday, A., King, A. C., Liedtka, J., \& Lockwood, T. (2010). The influence of design thinking in business: Some preliminary observations. Design Management Review, 21(3), 58-63.

Chung, K. W. (1998). The nature of design management: Developing a curriculum model. Design Management Journal (Former Series), 9(3), 66-71.

Chen, W., Colgate, E., Gerber, L., Gilbert, J., Herbst, W., Norman, D., . . Vance, J. (2010). Driving innovation through design: engineering in the 21st century. Paper presented at the NSF Workshop Report, Northwestern University, Evanston, IL.

McBride, M. (2007). Design management: future forward. Design Management Review, 18(3), 18-22.

Nam, K. Y., \& Jung, M. J. (2008). Bottom - up design leadership as a strategic tool. Design Management Review, 19(3), 59-67.

Turner, R., \& Topalian, A. (2002). Core responsibilities of design leaders in commercially demanding environments. Paper presented at the Inaugural Session Design Leadership Forum.

Miller, K., \& Moultrie, J. (2013). Understanding the skills of design leaders. Design Management Journal, 8(1), 35-51.

McClelland, D. C. (1973). Testing for competence rather than for" intelligence.". American psychologist, 28(1), 1.

McLagan, P. A. (1980). Competency models. Training and development Journal, 34(12), 22-26.

Boyatzis, R. E., Leonard, D., Rhee, K., \& Wheeler, J. V. (1996). Competencies can be developed, but not in the way we thought. Capability, 2(2), 25.

Sandberg, J. (2000). Understanding human competence at work: an interpretative approach. Academy of management journal, 43(1), 9-25.

Cockerill, T., Hunt, J., \& Schroder, H. (1995). Managerial competencies: fact or fiction? Business Strategy Review, 6(3), 1-12.

Bell, G., \& Fletcher, S. (1992). Competence in practice: the organisational perspective.

Byham, W. C. (1996). Developing dimension-/competency-based human resource systems. Development Dimensions International.

Ledford Jr, G. E. (1995). Paying for the skills, knowledge, and competencies of knowledge workers. Compensation \& Benefits Review, 27(4), 55-62.

Boyatzis, R. E. (1982). The competent manager: A model for effective performance: John Wiley \& Sons.

Dickson, P., Schneier, W., Lawrence, P., \& Hytry, R. (1995). Managing design in small high-growth companies. Journal of Product Innovation Management, 12(5), 406-414.

Chiva, R., \& Alegre, J. (2009). Investment in design and firm performance: The mediating role of design management. Journal of Product Innovation Management, 26(4), 424-440.

Kang, H.-J., Chung, K.-W., \& Nam, K. Y. (2015). A competence model for design managers: A case study of middle managers in Korea. International Journal of Design, 9(2). 
Aftab, M. (2013). Design as a functional leader: a case study to investigate the role of design as a potential leading discipline in multinational organisations: University of Northumbria at Newcastle (United Kingdom).

Dunne, D., \& Martin, R. (2006). Design thinking and how it will change management education: An interview and discussion. Academy of Management Learning \& Education, 5(4), 512-523.

Restrepo, J., \& Christiaans, H. (2004). Problem structuring and information access in design. Journal of Design Research, 4(2), 218-236.

Mullins, J. W., Mullins, J. W., Mullins, J., \& Komisar, R. (2009). Getting to plan B: Breaking through to a better business model: Harvard Business Press.

Linsey, J., Markman, A., \& Wood, K. (2012). Design by analogy: A study of the WordTree method for problem re-representation. Journal of Mechanical Design, 134(4).

Lee, K. C., \& Cassidy, T. (2007). Principles of design leadership for industrial design teams in Taiwan. Design Studies, 28(4), 437-462.

Van den Hende, E. A., Schoormans, J. P., Morel, K. P., Lashina, T., Van Loenen, E., \& de Boevere, E. I. (2007). Using early concept narratives to collect valid customer input about breakthrough technologies: The effect of application visualization on transportation. Technological Forecasting and Social Change, 74(9), 1773-1787.

Mugge, R., \& Dahl, D. W. (2013). Seeking the ideal level of design newness: Consumer response to radical and incremental product design. Journal of Product Innovation Management, 30, 34-47.

Elsbach, K., \& Flynn, F. J. (2008). Issues of identity in collaborations among creative professionals: A study of toy designers. UC Davis Graduate School of Management Research Paper(09-08).

Micheli, P., Jaina, J., Goffin, K., Lemke, F., \& Verganti, R. (2012). Perceptions of industrial design: The "means" and the "ends". Journal of Product Innovation Management, 29(5), 687-704.

Elsbach, K. D., Brown-Saracino, B., \& Flynn, F. J. (2015). Collaborating with creative peers. Harvard Business Review, 2015(October).

Wolfradt, U., \& Pretz, J. E. (2001). Individual differences in creativity: Personality, story writing, and hobbies. European journal of personality, 15(4), 297-310.

Lau, K., Beckman, S. L., \& Agogino, A. M. (2012). Diversity in design teams: An investigation of learning styles and their impact on team performance and innovation. International Journal of Engineering Education, 28(2), 293.

Waples, E. P., \& Friedrich, T. L. (2011). Managing creative performance: Important strategies for leaders of creative efforts. Advances in Developing Human Resources, 13(3), 366-385.

Shalley, C. E., \& Gilson, L. L. (2004). What leaders need to know: A review of social and contextual factors that can foster or hinder creativity. The leadership quarterly, 15(1), 33-53.

Lauche, K. (2007). Sketching the product strategy: Team processes in early design innovation. Journal of Design Research, 6(1-2), 45-60.

Turner, R. (2016). Design leadership: securing the strategic value of design: Routledge.

Langerak, F., Hultink, E. J., \& Griffin, A. (2008). Exploring mediating and moderating influences on the links among cycle time, proficiency in entry timing, and new product profitability. Journal of Product Innovation Management, 25(4), 370-385.

Ratneshwar, S., Shocker, A. D., Cotte, J., \& Srivastava, R. K. (1999). Product, person, and purpose: putting the consumer back into theories of dynamic market behaviour. Journal of Strategic Marketing, 7(3), 191-208.

Boyatzis, R., \& Boyatzis, R. E. (2008). Competencies in the 21st century. Journal of management development.

Noble, C. H., \& Kumar, M. (2010). Exploring the appeal of product design: A grounded, value - based model of key design elements and relationships. Journal of Product Innovation Management, 27(5), 640-657.

Moultrie, J., Clarkson, P. J., \& Probert, D. (2007). Development of a design audit tool for SMEs. Journal of Product Innovation Management, 24(4), 335-368.

Heskett, J., \& Liu, X. (2012). Models of developing design capacity: Perspective from China. Leading Through Design, 225. 
Storvang, P., Jensen, S., \& Christensen, P. R. (2014). Innovation through design: a framework for design capacity in a danish context. Design Management Journal, 9(1), 9-22.

Beckman, S. L., \& Barry, M. (2007). Innovation as a learning process: Embedding design thinking. California management review, 50(1), 25-56.

Cooper, R. G., \& Kleinschmidt, E. J. (1995). Benchmarking the firm's critical success factors in new product development. Journal of Product Innovation Management: AN INTERNATIONAL PUBLICATION OF THE PRODUCT DEVELOPMENT \& MANAGEMENT ASSOCIATION, 12(5), 374-391.

Dell'Era, C., \& Verganti, R. (2009). Design - driven laboratories: organization and strategy of laboratories specialized in the development of radical design - driven innovations. $R \& d$ Management, 39(1), 1-20.

Dell'Era, C., Marchesi, A., \& Verganti, R. (2010). Mastering technologies in design-driven innovation. Research-Technology Management, 53(2), 12-23.

Petre, M. (2004). How expert engineering teams use disciplines of innovation. Design Studies, 25(5), 477-493.

Im, S., \& Workman Jr, J. P. (2004). Market orientation, creativity, and new product performance in high-technology firms. Journal of marketing, 68(2), 114-132.

Acar, O. A., Tarakci, M., \& van Knippenberg, D. (2019). Creativity and innovation under constraints: A cross-disciplinary integrative review. Journal of Management, 45(1), 96-121.

Chiva, R., \& Chiva-gómez, R. (2014). The Facilitating Factors for Organizational Learning in the Ceramic Sector the ceramic sector. no. May.

Roper, S., Micheli, P., Love, J. H., \& Vahter, P. (2016). The roles and effectiveness of design in new product development: A study of Irish manufacturers. Research Policy, 45(1), 319-329.

Bloch, P. H. (1995). Seeking the ideal form: Product design and consumer response. Journal of marketing, 59(3), 16-29.

Kahn, K. B. (2001). Market orientation, interdepartmental integration, and product development performance. Journal of Product Innovation Management: AN INTERNATIONAL PUBLICATION OF THE PRODUCT DEVELOPMENT \& MANAGEMENT ASSOCIATION, 18(5), 314-323.

Gribbin, J., Spencer, N., \& Bailey, M. (2018). A Rapid Design - Led Approach to Innovation Readiness: Advantages and Challenges. Design Management Journal, 13(1), 4-16.

\section{Figures and Tables}

Table 3 Basic information of interviewees.

\begin{tabular}{|c|c|c|c|c|c|}
\hline Number & Company & $\begin{array}{l}\text { Company } \\
\text { Introduction }\end{array}$ & Position & $\begin{array}{l}\text { Years of } \\
\text { experience }\end{array}$ & Background \\
\hline 1 & $\begin{array}{l}\text { Airbnb } \\
\text { China }\end{array}$ & $\begin{array}{l}\text { American } \\
\text { multinational } \\
\text { company for } \\
\text { lodging }\end{array}$ & Head of Design & 15 & $\begin{array}{l}\text { Major in industrial design, senior } \\
\text { manager of a mature company and co- } \\
\text { founder of start-ups, engaged in the } \\
\text { design of smart phones, electronics, etc. }\end{array}$ \\
\hline 2 & TANG & $\begin{array}{l}\text { Leading Chinese } \\
\text { Design } \\
\text { Consultancy }\end{array}$ & Design Director & 9 & $\begin{array}{l}\text { Major in industrial design, middle design } \\
\text { manager, engaged in design of multiple } \\
\text { industrial sectors. }\end{array}$ \\
\hline 3 & YITU & $\begin{array}{l}\text { Leading Chinese } \\
\text { company in } \\
\text { solutions with } \\
\text { Al technologies }\end{array}$ & Design Lead & 7 & $\begin{array}{l}\text { Major in industrial design, Middle } \\
\text { managers of a fast-growing company, } \\
\text { engaged in software and hardware } \\
\text { design with artificial intelligence. }\end{array}$ \\
\hline 4 & RUNMI & $\begin{array}{l}\text { Leading Chinese } \\
\text { company in } \\
\text { providing smart } \\
\text { consumer goods }\end{array}$ & Design Partner & 11 & $\begin{array}{l}\text { Major in industrial design, founder of a } \\
\text { successful start-up, and a lecturer in } \\
\text { design management, engaged in the } \\
\text { design of suitcases and storage supplies. }\end{array}$ \\
\hline 5 & $B M W$ & $\begin{array}{l}\text { German } \\
\text { multinational }\end{array}$ & $\begin{array}{l}\text { Design Team } \\
\text { Leader }\end{array}$ & 8 & $\begin{array}{l}\text { Major in both industrial design and } \\
\text { business, junior manager, engaged in } \\
\text { smart interior design of vehicles. }\end{array}$ \\
\hline
\end{tabular}




\begin{tabular}{|c|c|c|c|c|c|}
\hline & & $\begin{array}{l}\text { company for } \\
\text { luxury vehicles }\end{array}$ & & & \\
\hline 6 & Haier & $\begin{array}{l}\text { Chinese } \\
\text { multinational } \\
\text { company for } \\
\text { home } \\
\text { appliances }\end{array}$ & $\begin{array}{l}\text { Creative Strategy } \\
\text { Director }\end{array}$ & 13 & $\begin{array}{l}\text { Major in marketing, senior manager, } \\
\text { engaged in the design of household } \\
\text { appliances and kitchen supplies. }\end{array}$ \\
\hline 7 & Frog Design & $\begin{array}{l}\text { Global design \& } \\
\text { innovation } \\
\text { consultancy }\end{array}$ & Design Director & 14 & $\begin{array}{l}\text { Major in industrial design, senior } \\
\text { manager, engaged in various fast-moving } \\
\text { consumer goods design and design } \\
\text { consulting services. }\end{array}$ \\
\hline 8 & JD.com & $\begin{array}{l}\text { Leading Chinese } \\
\text { e-commerce } \\
\text { company }\end{array}$ & Product Manager & 7 & $\begin{array}{l}\text { Major in industrial design, transformed } \\
\text { from a middle-level design manager to a } \\
\text { product manager, engaged in design of } \\
\text { virtual reality software and hardware. }\end{array}$ \\
\hline
\end{tabular}

Table 4 Basic information of survey respondents.

\begin{tabular}{|c|c|c|c|}
\hline Survey Items & Features & Number of respondents & Proportion \\
\hline \multirow{2}{*}{ Gender } & Male & 35 & $57.40 \%$ \\
\hline & Female & 26 & $42.60 \%$ \\
\hline \multirow{4}{*}{ Age } & $25-30$ & 26 & $42.60 \%$ \\
\hline & $31-40$ & 27 & $44.26 \%$ \\
\hline & $41-50$ & 7 & $11.48 \%$ \\
\hline & $>50$ & 1 & $1.64 \%$ \\
\hline \multirow{4}{*}{ Position } & Junior manager & 33 & $54.10 \%$ \\
\hline & Middle manager & 20 & $32.79 \%$ \\
\hline & Senior manager & 4 & $6.56 \%$ \\
\hline & Entrepreneur/Business Owner & 4 & $6.56 \%$ \\
\hline \multirow{4}{*}{ Education } & High School & 1 & $1.64 \%$ \\
\hline & Bachelor & 32 & $52.46 \%$ \\
\hline & Master & 26 & $42.62 \%$ \\
\hline & $P h D$ & 2 & $3.28 \%$ \\
\hline \multirow{2}{*}{ Background } & Design & 47 & $77.05 \%$ \\
\hline & Non-design & 14 & $22.95 \%$ \\
\hline \multirow{4}{*}{$\begin{array}{l}\text { Enterprise } \\
\text { staff size }\end{array}$} & $0-300$ & 16 & $26.23 \%$ \\
\hline & $300-500$ & 2 & $3.28 \%$ \\
\hline & $500-1000$ & 4 & $6.56 \%$ \\
\hline & $>1000$ & 38 & $62.30 \%$ \\
\hline \multirow{4}{*}{$\begin{array}{c}\text { Enterprise } \\
\text { development stage }\end{array}$} & Early stage & 8 & $13.11 \%$ \\
\hline & Growth & 15 & $24.59 \%$ \\
\hline & Maturity & 28 & $45.90 \%$ \\
\hline & Transition & 10 & $16.39 \%$ \\
\hline
\end{tabular}


Table 5 Initial analysis of competencies.

\begin{tabular}{|c|c|c|c|}
\hline Number & Competency clusters & Mean & $S D$ \\
\hline 1 & $\begin{array}{l}\text { Be able to possess stress resistance, subjective initiative and self-learning, and push } \\
\text { personal growth. }\end{array}$ & 5.967 & 0.930 \\
\hline 2 & Be able to have logical analysis, systematic thinking, forward-looking thinking. & 5.885 & 0.858 \\
\hline 3 & $\begin{array}{l}\text { Be able to possess comprehensive, in-depth and leading design knowledge and } \\
\text { practical skills, together with open and iterative way of thinking. }\end{array}$ & 5.738 & 1.047 \\
\hline 4 & $\begin{array}{l}\text { Be able to communicate and understand when working across teams, and effectively } \\
\text { convey the value of design, and reach consensus on goals. }\end{array}$ & 5.721 & 0.933 \\
\hline 5 & $\begin{array}{l}\text { Be able to manage the design process, stimulate creativity, control the direction, make } \\
\text { decisions, and ensure the quality of output. }\end{array}$ & 5.557 & 0.940 \\
\hline 6 & Be able to formulate specific design project plans based on corporate strategy. & 5.475 & 1.074 \\
\hline 7 & Be able to build trust and lead the team to improve work results. & 5.443 & 1.057 \\
\hline 8 & $\begin{array}{l}\text { Be able to interpret and analyse user data, understand user needs and refine them into } \\
\text { developable concepts. }\end{array}$ & 5.443 & 1.118 \\
\hline 9 & Be able to personalize the management and training of designers. & 5.377 & 1.171 \\
\hline 10 & $\begin{array}{l}\text { Be able to analyse the market and competitors, make design strategy and manage the } \\
\text { design assets. }\end{array}$ & 5.328 & 0.961 \\
\hline 11 & Be able to form a suitable team and formulate a development route. & 5.279 & 1.142 \\
\hline 12 & Be able to have the business and technical knowledge required by the organization. & 5.213 & 0.878 \\
\hline 13 & $\begin{array}{l}\text { Be able to win the resource support from the company's senior management and } \\
\text { stakeholders for design function. }\end{array}$ & 5.164 & 1.172 \\
\hline
\end{tabular}

Table 6 Initial analysis of organizational factors.

\begin{tabular}{lllc}
\hline Organizational factors & Descriptions & Mean & SD \\
\hline Organizational culture & $\begin{array}{l}\text { Company has a culture that values design, supports creativity, and is } \\
\text { user-centred. }\end{array}$ & 5.295 & 0.989 \\
\hline $\begin{array}{l}\text { Organizational } \\
\text { structure }\end{array}$ & Design function is involved in multiple stages of product development. & 5.295 & 1.243 \\
\hline Organizational strategy & $\begin{array}{l}\text { Company invests more human and financial resources in the design } \\
\text { function. }\end{array}$ & 4.689 & 1.409 \\
\hline
\end{tabular}

Table 7 Results of exploratory factor analysis for competencies.

\begin{tabular}{llllll}
\hline Survey items & Factor 1 & Factor 2 & Factor 3 & Factor 4 & Factor 5 \\
& Design & Design & Design & Design & Design \\
& Team & Profession & Manage- & Business & Resource \\
& Leadership & & ment & Strategy & Gathering \\
& & & Thinking & \\
& & & & \\
\end{tabular}


Be able to form a suitable team and formulate a

development route.

Be able to build trust and lead the team to improve

.740

work results.

Be able to personalize the management and

.740

.558

training of designers.

Be able to manage the design process, stimulate creativity, control the direction, make decisions, and ensure the quality of output.

Be able to analyse the market and competitors, make design strategy and manage the design assets.

Be able to communicate and understand when working across teams, and effectively convey the value of design, and reach consensus on goals.

Be able to possess comprehensive, in-depth and leading design knowledge and practical skills, together with open and iterative way of thinking.

Be able to interpret and analyse user data, understand user needs and refine them into developable concepts.

Be able to have logical analysis, systematic thinking, forward-looking thinking.

Be able to possess stress resistance, subjective initiative and self-learning, and push personal growth.

Be able to formulate specific design project plans 


\begin{tabular}{|c|c|c|c|c|c|}
\hline \multirow[t]{2}{*}{ Model } & \multicolumn{2}{|c|}{ Unstandardized Coefficients } & Standardized Coefficients & \multirow[t]{2}{*}{$t$} & \multirow[t]{2}{*}{ Sig. } \\
\hline & $B$ & Std. Error & Beta & & \\
\hline $\begin{array}{l}\text { Company has a culture that values } \\
\text { design, supports creativity, and is } \\
\text { user-centred. }\end{array}$ & .337 & .163 & .431 & 2.066 & .044 \\
\hline
\end{tabular}

a. Dependent Variable: Design Team Leadership

\begin{tabular}{|c|c|c|c|c|c|}
\hline \multirow[t]{2}{*}{ Model } & \multicolumn{2}{|c|}{ Unstandardized Coefficients } & Standardized Coefficients & \multirow[t]{2}{*}{$t$} & \multirow[t]{2}{*}{ Sig. } \\
\hline & B & Std. Error & Beta & & \\
\hline $\begin{array}{l}\text { Design function is involved in } \\
\text { multiple stages of product } \\
\text { development. }\end{array}$ & .369 & .125 & .379 & 2.956 & .005 \\
\hline
\end{tabular}

a. Dependent Variable: Design Management Thinking

\begin{tabular}{|c|c|c|c|c|c|}
\hline \multirow[t]{2}{*}{ Model } & \multicolumn{2}{|c|}{ Unstandardized Coefficients } & \multirow[t]{2}{*}{ Standardized Coefficients } & \multirow[t]{2}{*}{$t$} & \multirow[t]{2}{*}{ Sig. } \\
\hline & $B$ & Std. Error & & & \\
\hline $\begin{array}{l}\text { Design function is involved in } \\
\text { multiple stages of product } \\
\text { development. }\end{array}$ & .281 & .124 & .288 & 2.27 & .027 \\
\hline $\begin{array}{l}\text { Company has a culture that values } \\
\text { design, supports creativity, and is } \\
\text { user-centred. }\end{array}$ & -.349 & .099 & -.446 & -3.509 & .001 \\
\hline
\end{tabular}

a. Dependent Variable: Design Business Strategy

\begin{tabular}{|c|c|c|c|c|c|}
\hline \multirow[t]{2}{*}{ Model } & \multicolumn{2}{|c|}{ Unstandardized Coefficients } & Standardized Coefficients & \multirow[t]{2}{*}{$t$} & \multirow[t]{2}{*}{ Sig. } \\
\hline & $B$ & Std. Error & Beta & & \\
\hline $\begin{array}{l}\text { Company invests more human and } \\
\text { financial resources in the design } \\
\text { function. }\end{array}$ & .233 & .091 & .335 & 2.563 & .013 \\
\hline
\end{tabular}

a. Dependent Variable: Design Resource Gathering

Table 9 A competency model for design managers. 


\section{Dimension 1. Design Team Leadership}

Cluster 1.1 Be able to form a suitable team and formulate a development route.

$>\quad$ Find suitable and excellent designers, select and form a design team that meets business needs.

$>\quad$ Formulate the short-term and long-term goals of design, conceive a convincing and inspiring vision for the designers.

Cluster 1.2 Be able to build trust and lead the team to improve work results.

$>\quad$ Create an open, inclusive, supportive, and collaborative team atmosphere, build team trust and cohesion.

$>\quad$ Lead the team to review the project, summarize experience and lessons and improve future work results.

$>\quad$ Build authority through design expertise, consistent behaviour and other personality charms, win trust of members.

Cluster 1.3 Be able to personalize the management and training of designers.

$>\quad$ Understand designer's working style, stimulate the enthusiasm of design team members and drive them effectively.

$>\quad$ Observe the needs, difficulties, emotions and conflicts of design team members, communicate and intervene effectively.

$>\quad$ Define clear job responsibilities and assign tasks according to the characteristics and expertise of design team members.

$>\quad$ Cultivate design team members through encouragement, reward, education, training, promotion, etc., help them clarify the career path.

Cluster 1.4 Be able to manage the design process, stimulate creativity, control the direction, make decisions, and ensure the quality of output.

$>\quad$ Manage the design process, provide effective and specific feedbacks, formulate design standards.

$>\quad$ Stimulate the creativity of the team.

$>\quad$ Control the project direction, correct the deviations between the plan and the actual situation, and make decisive, timely and thorough decisions.

$>\quad$ Control the time, manpower and financial resources, monitor the output of key nodes, and ensure that the work objectives are effectively achieved.

$>\quad$ Understand user needs and refine them into developable concepts.

$>\quad$ Have user thinking, such as user insights, user sensibility and empathy.

Cluster 1.5 Be able to analyse the market and competitors, make design strategy and manage the design assets.

$>\quad$ Understand the market, the positioning of competitors, the company's strategic intentions and decisions, and identify possible opportunities.

$>\quad$ Value and manage the company's strategic design assets, such as design outlines, brand recognition, product design planning, etc.

\section{Dimension 2. Design Profession}

Cluster 2.1 Be able to communicate and understand when working across teams, and effectively convey the value of design, and reach consensus on goals.

$>\quad$ Communicate fully when working across teams, understand each other's intentions, negotiate and handle conflicts, have a holistic view, reach consensus.

$>\quad$ Choose language, presentation forms and evidence according to targets, convey the value of the design plan, persuade and gain recognition.

Cluster 2.2 Be able to possess comprehensive, in-depth and leading design knowledge and practical skills, together with open and iterative way of thinking.

Have comprehensive, in-depth and leading theoretical knowledge, software and hardware operating skills in multifields of design.

$>\quad$ Communicate and think through visual methods such as sketching and rapid prototyping.

$>\quad$ Have openness and innovation ability, spend time thinking about new solutions, try untraditional methods.

$>\quad$ Have iterative thinking and believe that problems and solutions evolve together. 
Cluster 2.3 Be able to interpret and analyse user data, deeply understand user needs and refine them into developable concepts.

$>$ Interpret and analyse product-related information and data, synthesize to draw clear and concise conclusions.

\section{Dimension 3. Design Management Thinking}

Cluster 3.1 Be able to have logical analysis, systematic thinking, forward-looking thinking.

$>\quad$ Analyse logically and think systematically, focus on the overall situation and multiple angles, find the root cause.

$>\quad$ Have forward-looking thinking, have the awareness of future, predict possible development and changes.

Cluster 3.2 Be able to possess stress resistance, subjective initiative and self-learning, and push personal growth.

$>\quad$ Possess good subjective initiative and self-learning, require continuous self-growth, and constantly improve the knowledge and practices.

$>\quad$ Resist stress, adapt to changes in the environment and identity, and actively control and regulate personal emotions.

\section{Dimension 4. Design Business Strategy}

Cluster 4.1 Be able to formulate specific design project plans based on corporate strategy.

$>\quad$ Clarify design project goals, prioritize, understand needs, resources, risks and constraints based on corporate strategy, and formulate project plans.

$>\quad$ Allocate human resources and financial budgets to various design projects.

$>\quad$ Establish a network of relationships with external customers, business partners, etc., and obtain support.

Cluster 4.2 Be able to have the business and technical knowledge required by the organization.

$>\quad$ Possess business knowledge and skills, such as business model, marketing and financial terminology.

$>\quad$ Possess engineering and technical knowledge and skills.

\section{Dimension 5. Design Resource Gathering}

Cluster 5.1 Be able to win the resource support from the company's senior management and stakeholders for design function.

$>\quad$ Help senior management's gain in-depth understanding and positive views on design function, establish trust and obtain resources.

Author Bios:

Chen Xiang Research Associate in Peking University Shenzhen Graduate School, focusing on technology innovation studies. Chen accomplished a master of design strategy and management in School of Design and Innovation, Tongji University. 
Wenqing Yang Associate Professor of School of Design and Innovation, Tongji University, head of the teaching team for the Master of Industrial Design, founder of LOE DESIGN, focusing on research of product system integration design and user experience design.

Wei Liu Senior Lecturer (Associate Professor) at King's College London with extensive teaching and research experience across design, engineering and management. She accomplished her PhD at the University of Cambridge and was a Visiting Fellow at Harvard University to explore interdisciplinary design education. 